\title{
Oxidation of Ethanol in Cu-Faujasites Studied by IR Spectroscopy
}

\author{
Łukasz Kuterasiński (D), Jerzy Podobiński and Jerzy Datka *D \\ Jerzy Haber Institute of Catalysis and Surface Chemistry, Polish Academy of Sciences, ul. Niezapominajek 8 , \\ 30-239 Kraków, Poland; nckutera@cyf-kr.edu.pl (Ł.K.); ncpodobi@cyf-kr.edu.pl (J.P.) \\ * Correspondence: datka@chemia.uj.edu.pl
}

Citation: Kuterasiński, Ł.;

Podobiński, J.; Datka, J. Oxidation of Ethanol in Cu-Faujasites Studied by IR Spectroscopy. Molecules 2021, 26, 2669. https://doi.org/10.3390/ molecules26092669

Academic Editor:

Alfonso Martinez-Felipe

Received: 9 March 2021

Accepted: 28 April 2021

Published: 2 May 2021

Publisher's Note: MDPI stays neutral with regard to jurisdictional claims in published maps and institutional affiliations.

Copyright: (c) 2021 by the authors. Licensee MDPI, Basel, Switzerland. This article is an open access article distributed under the terms and conditions of the Creative Commons Attribution (CC BY) license (https:// creativecommons.org/licenses/by/ $4.0 /)$.

\begin{abstract}
In this study, IR studies of the coadsorption of ethanol and $\mathrm{CO}$ on $\mathrm{Cu}^{+}$cations evidenced the transfer of electrons from ethanol to $\mathrm{Cu}^{+}$, which caused the lowering of the frequency of the band attributed to $\mathrm{CO}$ bonded to the same $\mathrm{Cu}^{+}$cation due to the more effective $\pi$ back donation of $\mathrm{d}$ electrons of $\mathrm{Cu}$ to antibonding $\pi^{*}$ orbitals of $\mathrm{CO}$. The reaction of ethanol with acid sites in zeolite HFAU above $370 \mathrm{~K}$ produced water and ethane, polymerizing to polyethylene. Ethanol adsorbed on zeolite $\mathrm{Cu}(2)$ HFAU containing acid sites and $\mathrm{Cu}^{+}$exch also produced ethene, but in this case, the ethene was bonded to $\mathrm{Cu}^{+}$and did not polymerize. $\mathrm{C}=\mathrm{C}$ stretching, which is IR non-active in the free ethene molecule, became IR active, and a weak IR band at $1538 \mathrm{~cm}^{-1}$ was present. The reaction of ethanol above $370 \mathrm{~K}$ in $\mathrm{Cu}(5) \mathrm{NaFAU}$ zeolite (containing small amounts of $\mathrm{Cu}^{+}$exch and bigger amounts of $\mathrm{Cu}^{+}{ }_{\text {ox }}, \mathrm{Cu}^{2+}$ exch and $\mathrm{CuO}$ ) produced acetaldehyde, which was further oxidized to the acetate species $\left(\mathrm{CH}_{3} \mathrm{COO}^{-}\right)$. As oxygen was not supplied, the donors of oxygen were the $\mathrm{Cu}$ species present in our zeolite. The $\mathrm{CO}$ and $\mathrm{NO}$ adsorption experiments performed in $\mathrm{Cu}$-zeolite before and after ethanol reaction evidenced that both $\mathrm{Cu}^{+}$ox and $\mathrm{Cu}^{2+}\left(\mathrm{Cu}^{2+}\right.$ exch and $\left.\mathrm{CuO}\right)$ were consumed by the ethanol oxidation reaction. The studies of the considered reaction of bulk $\mathrm{CuO}$ and $\mathrm{Cu}_{2} \mathrm{O}$ as well as zeolites, in which the contribution of $\mathrm{Cu}^{+}$ox species was reduced by various treatments, suggest that ethanol was oxidized to acetaldehyde by $\mathrm{Cu}^{2+}$ ox (the role of $\mathrm{Cu}^{+}{ }_{\text {ox }}$ could not be elucidated), but $\mathrm{Cu}^{+}$ox was the oxygen donor in the acetate formation.
\end{abstract}

Keywords: ethanol oxidation; Cu species; faujasite

\section{Introduction}

$\mathrm{Cu}$-containing zeolites gained a great deal of attention because of their activity in the decomposition or reduction of nitrogen oxides [1-13], the ability of activation of multiple bonds in organic molecules [14-20] and the catalytic activity in various organic molecules. Alcohol oxidation is one of such reactions catalyzed by copper containing zeolites [21-37]. For instance, Tsuruva et al. [21] investigated the vapor-phase oxidation of benzyl alcohol over $\mathrm{CuNa}-\mathrm{Y}$ zeolite in the temperature range of 573 to $663 \mathrm{~K}$. The main products were $\mathrm{CO}$, $\mathrm{CO}_{2}$, and benzaldehyde. $\mathrm{Cu}(\mathrm{II})$ ion was found as the main active site for this reaction. The benzaldehyde formation rate was well described by the following equation:

$$
\left.\mathrm{r}_{\varphi \mathrm{CHO}}=\mathrm{k} \cdot\left[\mathrm{O}_{2}\right]^{1}\left[\varphi \mathrm{CH}_{2} \mathrm{OH}\right]^{-1}\right)
$$

with the activation energy of $57.0 \mathrm{~kJ} / \mathrm{mol}$. Furthermore, it was indicated that the catalytic activity for the oxidation of benzyl alcohol depended on the addition of amine to reaction system. The addition of piperidine decreased, and the addition of pyridine increased, the oxidation activity. From Electron Spin Resonance (ESR) measurements of $\mathrm{Cu}(\mathrm{II}) \mathrm{NaY}$-amine systems, it was evidenced that the strength of the covalent bonding between $\mathrm{Cu}(\mathrm{II})$ and piperidine was stronger in comparison with pyridine. It was also found that the addition of $\mathrm{CO}$ and $\mathrm{H}_{2}$ into the reaction system decreased the conversion of benzyl alcohol and changed the selectivity to benzaldehyde, which was higher for hydrogen, on the other hand, a water-deactivated catalyst. 
In another work, Tsuruva et al. [22] reported the gas-phase oxidation of ethanol over $\mathrm{CuNa}-\mathrm{Y}$ at $523-623 \mathrm{~K}$. Acetaldehyde was formed as the main oxidation product in the whole temperature range. It was also evidenced that $\mathrm{Cu}(\mathrm{II})$ ions were the active sites responsible for the oxidative dehydrogenation of ethanol. Kinetic studies of acetaldehyde formation over the CuNa-Y catalyst evidenced that the acetaldehyde formation rate was reciprocal, first order in ethanol and one-half order in relation to the partial pressure of oxygen, according to the Equation (1), with the activation energy of $70.0 \mathrm{~kJ} / \mathrm{mol}$.

$$
\mathrm{r}_{\mathrm{CH} 3 \mathrm{CHO}}=\mathrm{kP}^{-1}{ }_{\mathrm{C} 2 \mathrm{H} 5 \mathrm{OH}} \mathrm{P}^{1 / 2} \mathrm{O} 2
$$

Bun et al. [23] investigated ZSM-5 type zeolites containing protons or $\mathrm{Cu}^{\mathrm{II}}$ as catalysts for the ethanol conversion under the atmosphere, both in the presence and absence of oxygen. Analysis of the collected data led to the conclusion that the protonic acid sites present in ZSM-5 favored the dehydration of ethanol toward ethene, irrespective of the presence of oxygen in the reaction system. In turn, $\mathrm{Cu}(\mathrm{II})$ ion in the ZSM-5 promoted the oxidation of ethanol, which led to the production of $\mathrm{CO}$ and $\mathrm{CO}_{2}$.

Alcohol can be used not only as a precursor, but also as a reducing agent in the selective catalytic reduction of nitrogen oxides. The influence of the copper content $(0.3,1.5$ and $3.3 \mathrm{wt} . \%$ ) on the catalytic properties of $\mathrm{Cu}_{\mathrm{x}} \mathrm{SiBEA}$ zeolites in SCR of NO by ethanol was investigated by Janas et al. [38]. According to XRD, DR UV-vis-NIR and XPS results, copper incorporated into the dealuminated SiBEA zeolite was present mainly in the form of isolated tetracoordinated $\mathrm{Cu}(\mathrm{II})$. $\mathrm{Cu}_{0.3} \mathrm{SiBEA}, \mathrm{Cu}_{1.5} \mathrm{SiBEA}$ and $\mathrm{Cu}_{3.3} \mathrm{SiBEA}$ were active in SCR, for which NO conversions at $573 \mathrm{~K}$ were $33 \%, 45.5 \%$ and $50 \%$, whereas the selectivity to $\mathrm{N}_{2}$ was $90 \%, 97 \%$ and $75 \%$, respectively. Basing on these results, it was concluded that the SCR of NO took place on isolated tetracoordinated $\mathrm{Cu}^{2+}$ in the absence of $\mathrm{Al}$ atoms. Conversion of $\mathrm{NO}$ increased with copper content, while selectivity to $\mathrm{N}_{2}$ was independent of the amount of $\mathrm{Cu}$.

In our earlier paper [39], we reported that the way of preparation of copper containing faujasite-type zeolite of $\mathrm{Si} / \mathrm{Al}=31$ determined the status and properties of $\mathrm{Cu}$ sites in these catalysts. Cu was found in the form of monovalent cation occurring both in exchange extraframework positions $\left(\mathrm{Cu}^{+}\right.$exch $)$and as oxides $\left(\mathrm{Cu}^{+}{ }_{\text {ox }}\right)$, as well as in the form of divalent species $\left(\mathrm{Cu}^{2+}\right.$ exch and $\left.\mathrm{CuO}\right)$. $\mathrm{Cu}$ cations in the exchange extra framework positions are ions, which neutralize the negative charge of $\mathrm{AlO}_{4}{ }^{-}$tetrahedral. The cations in oxide forms are neutralized by the negative charge of the framework, which is neutralized by protons or exchange cations. The amounts of $\mathrm{Cu}$ forms depended on the copper content in zeolites and on the form of zeolite support of the faujasite structure of $\mathrm{Si} / \mathrm{Al}=31$ to which $\mathrm{Cu}$ was incorporated: commercial dealuminated faujasite in protonic form (HFAU) or faujasite after ion-exchange with $\mathrm{NaNO}_{3}$ (NaFAU). The former type of zeolites (CuHFAU) contained mainly $\mathrm{Cu}^{+}$exch, while for $\mathrm{CuNaFAU}$-type zeolites, much higher amounts of $\mathrm{Cu}^{+}$ox and $\mathrm{Cu}^{2+}$ were found. Furthermore, it was indicated that both $\mathrm{Cu}^{+}$and $\mathrm{Cu}^{2+}$ in oxide forms showed stronger electrodonor properties in comparison with $\mathrm{Cu}^{+}$and $\mathrm{Cu}^{2+}$ in the exchange form.

We also reported the process of reduction and oxidation of the $\mathrm{Cu}$ species in $\mathrm{Cu}$ FAU [40]. In our study, reducers were hydrogen and ethanol, while the role oxidizers played were oxygen and NO. In the reduction experiments, it was revealed that $\mathrm{Cu}^{+}$ox and $\mathrm{Cu}^{2+}$ exch were more prone to reduction by hydrogen than $\mathrm{Cu}^{+}$exch and $\mathrm{Cu}^{2+}{ }_{\text {ox }}$ Ethanol caused reduction mainly for $\mathrm{Cu}^{2+}$ and partially for $\mathrm{Cu}^{+}$.

The present study concerns the reaction of ethanol with the $\mathrm{Cu}$ species in $\mathrm{Cu}$-zeolites. Two zeolites were studied: $\mathrm{Cu}(2) \mathrm{HFAU}$ and $\mathrm{Cu}(5) \mathrm{NaFAU}$. These zeolites contained 2 and $5 \mathrm{wt} . \%$ of $\mathrm{Cu}$, respectively. Copper was introduced by impregnation to the protonic (HFAU) or sodium form of faujasite (NaFAU), respectively. Zeolite $\mathrm{Cu}(2) \mathrm{HFAU}$ contained mostly $\mathrm{Cu}^{+}$exch, whereas in $\mathrm{Cu}(5) \mathrm{NaFAU}$, relatively large amounts of both $\mathrm{Cu}^{+}{ }_{\text {ox }}$ and $\mathrm{Cu}^{2+}$, and smaller $\mathrm{Cu}^{+}$exch contents were found. That allowed us to determine the ability of various $\mathrm{Cu}$ species (i.e., copper in exchange positions as well as $\mathrm{Cu}$ in the form of oxides) in the oxidation of ethanol. We also studied the coadsorption of ethanol and CO molecules on 
$\mathrm{Cu}^{+}$cations. This informed how the interaction of $\mathrm{Cu}^{+}$with ethanol changes the electronic properties of $\mathrm{Cu}^{+}$.

\section{Results and Discussion}

\subsection{Coadsorption of Ethanol and $C O$}

In order to learn how the interaction of $\mathrm{Cu}^{+}$ions with ethanol molecules modifies the electronic properties of $\mathrm{Cu}^{+}$, we performed the coadsorption of ethanol and $\mathrm{CO}$ molecules over $\mathrm{Cu}(2) \mathrm{HFAU}$. Sorption of ethanol at room temperature was followed by the sorption of $\mathrm{CO}$ on the studied catalyst at the same temperature. The spectrum of $\mathrm{CO}$ interacting with $\mathrm{Cu}^{+}$exch showed the band at $2158 \mathrm{~cm}^{-1}$, which was also observed in our previous studies $[39,40]$ and was reported by other authors [3,41-43]. When ethanol was preadsorbed, the $\mathrm{Cu}^{+}$exch-CO band was shifted to lower frequencies and the two shifted maxima appeared at 2118 and $2134 \mathrm{~cm}^{-1}$ (Figure 1). Lowering the CO stretching frequency is the result of electron transfer from the ethanol molecule to $\mathrm{Cu}^{+}$ion and the more efficient effect of $\pi$-back donation of d-electrons of $\mathrm{Cu}^{+}$to $\pi^{*}$ antibonding orbitals of CO. Similar effects were observed in earlier studies of coadsorption of other molecules, such as but-1-ene, benzene, acetone and $\mathrm{CO}$ on $\mathrm{Cu}^{+}$in CuZSM-5 [44]. Two bands assigned to $\mathrm{Cu}^{+}{ }_{\text {exch }}$ interacting simultaneously with CO and ethanol molecules $\left(2118\right.$ and $\left.2134 \mathrm{~cm}^{-1}\right)$ suggested the occurrence of two kinds of $\mathrm{Cu}^{+}$exch ions of different electrondonor properties. It may be the result of the presence of two kinds of $\mathrm{Cu}^{+}$exch modified to various extents by electron transfer from ethanol molecules.

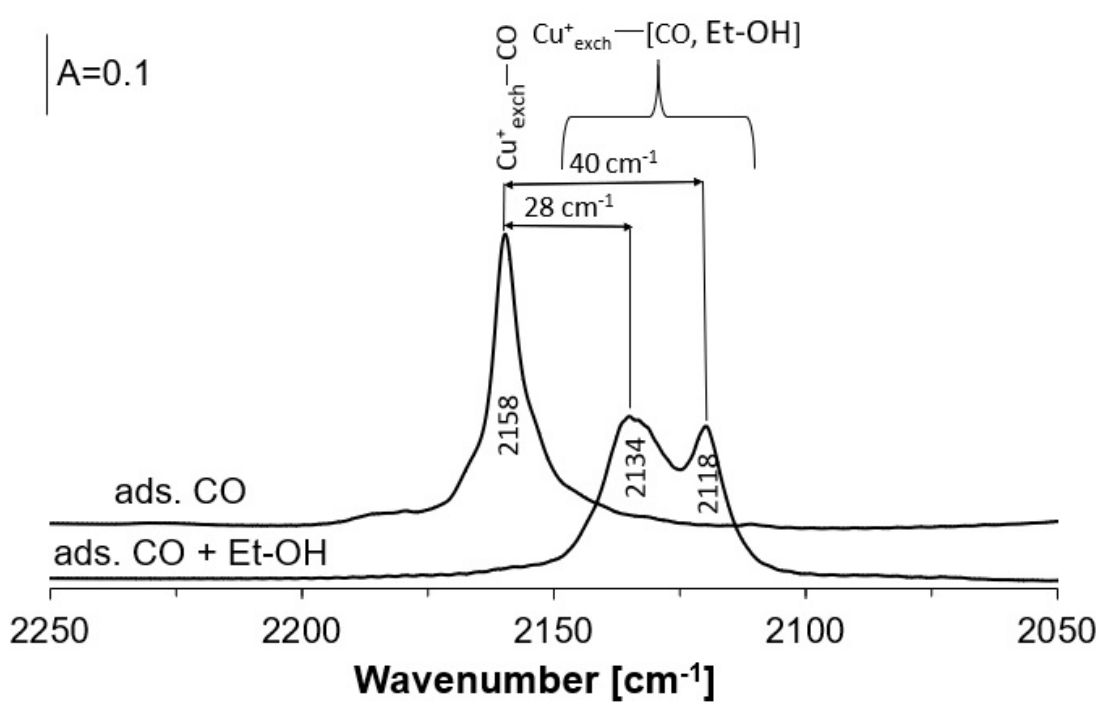

Figure 1. The spectrum of $\mathrm{CO}$ sorbed in zeolite $\mathrm{Cu}(2) \mathrm{HFAU}$ and the same zeolite with preadsorbed ethanol.

\subsection{Reaction of Ethanol in HFAU}

As $\mathrm{Cu}$-zeolites contain not only $\mathrm{Cu}$ sites but also Brønsted acid sites ( $\mathrm{Si}-\mathrm{OH}-\mathrm{Al}$ groups, Figure 2A), we studied the transformations of ethanol sorbed in zeolite HFAU containing only protonic sites. The spectra recorded upon the sorption of ethanol in HFAU at room temperature, followed by heating to 370, 450, 510 and $570 \mathrm{~K}$, are presented in Figure 3A. Upon each heating step, the cell with the zeolite was cooled to room temperature. The spectrum of ethanol physisorbed at room temperature showed the bands of $\mathrm{CH}_{3}$ and $\mathrm{CH}_{2}$ deformation vibrations at 1395 and $1450 \mathrm{~cm}^{-1}$.

Heating to $370 \mathrm{~K}$ does not change the spectrum of ethanol, but at $450 \mathrm{~K}$, the bands of ethanol decreased and a new weak and narrow band at $1490 \mathrm{~cm}^{-1}$ appeared. This band increased upon heating to $510 \mathrm{~K}$. This band may be attributed to polyethylene [45]. The increase in broad absorption band around $1600-1700 \mathrm{~cm}^{-1}$ may be due to water formation. These results can be explained by the dehydration of ethanol on very strong protonic sites, 
producing water and ethene, which polymerizes, forming polyethylene. Dehydration of ethanol in the presence of acid sites in zeolites ZSM- 5 was also reported by Bun et al. [23].

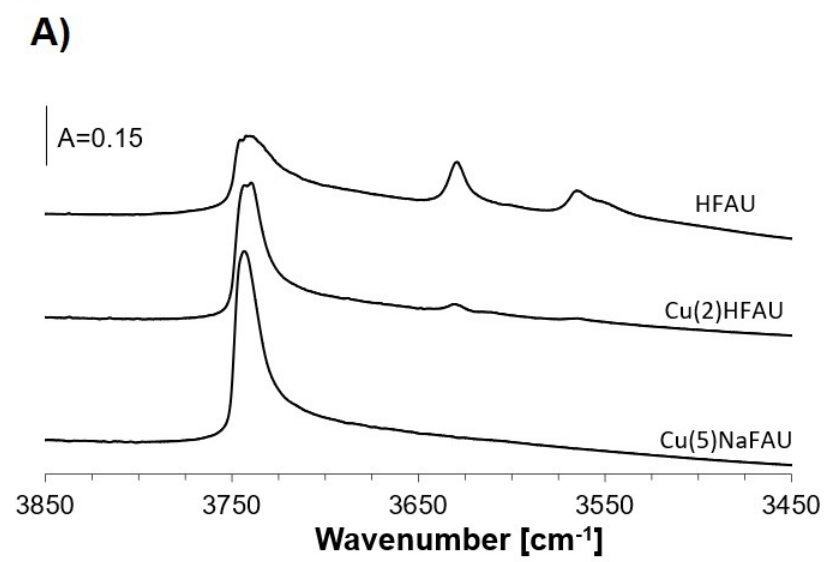

B)

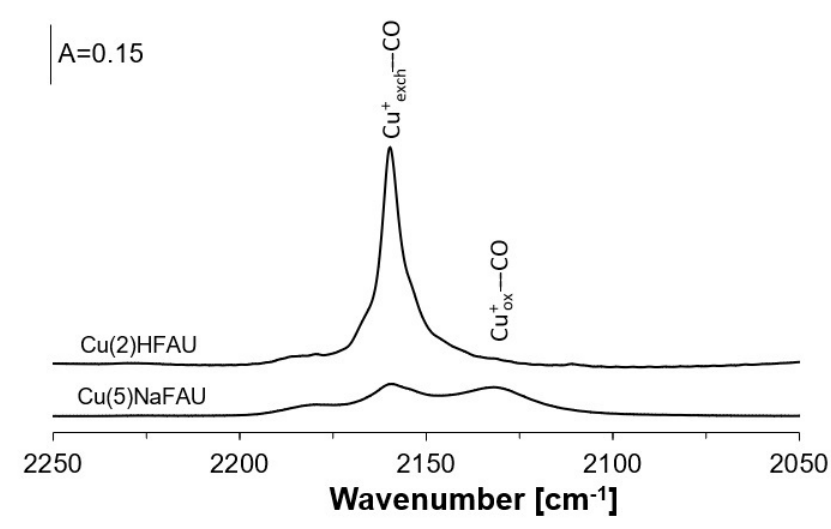

C)

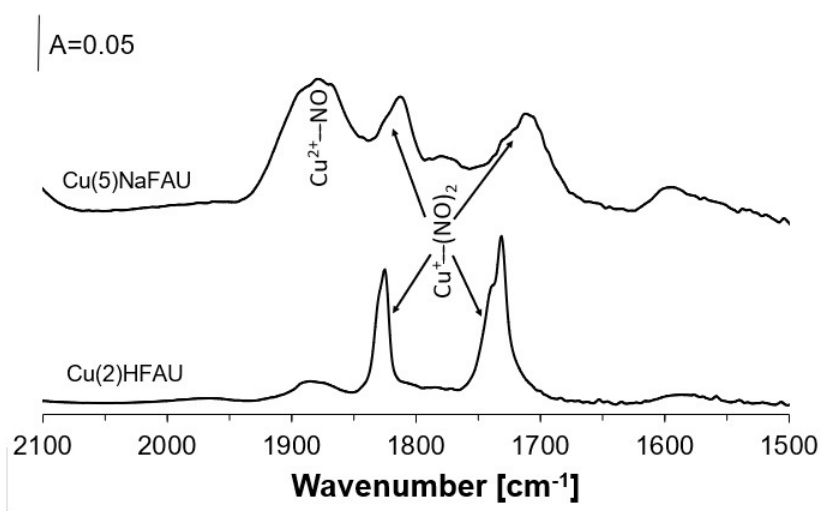

Figure 2. (A) The spectra of $\mathrm{OH}$ groups in zeolites HFAU, $\mathrm{Cu}(2) \mathrm{HFAU}$ and $\mathrm{Cu}(5) \mathrm{NaFAU}$; $\mathrm{B}, \mathrm{C}-$ the spectra of $\mathrm{CO}$ sorbed at room temperature in zeolites $\mathrm{Cu}(2) \mathrm{HFAU}(\mathbf{B})$ and of $\mathrm{NO}$ sorbed in $\mathrm{Cu}(5) \mathrm{NaFAU}$ at $190 \mathrm{~K}(\mathrm{C})$.

\subsection{Reaction of Ethanol in $\mathrm{Cu}(2) \mathrm{HFAU}$}

Zeolite $\mathrm{Cu}(2) \mathrm{HFAU}$ contains a large amount of $\mathrm{Cu}^{+}$exch, but much smaller amounts of $\mathrm{Cu}^{2+} \mathrm{Cu}^{+}$ox are absent. This was evidenced in the experiments of $\mathrm{CO}$ and NO sorption (Figure $2 \mathrm{~B}, \mathrm{C}$ ), in which an intense $2158 \mathrm{~cm}^{-1}$ band of $\mathrm{Cu}^{+}-\mathrm{CO}$ and relatively weak $1850-1900 \mathrm{~cm}^{-1}$ band of $\mathrm{Cu}^{2+}-\mathrm{NO}$ as well as the absence of $2130 \mathrm{~cm}^{-1}$ band of $\mathrm{Cu}^{+}{ }_{\text {ox }}-\mathrm{CO}$ were seen. 
The spectrum of ethanol sorbed at room temperature in zeolite $\mathrm{Cu}(2) \mathrm{HFAU}$ is presented in Figure 3B. Heating to $370 \mathrm{~K}$ does not change the spectrum; however, heating to temperatures higher than $370 \mathrm{~K}$ produces ethene, characterized by the bands at $1428 \mathrm{~cm}^{-1}$ (deformation of $\mathrm{CH}_{2}$ ) and a weaker one at $1538 \mathrm{~cm}^{-1}$ of $\mathrm{C}=\mathrm{C}$ stretching. This last band is very weak because the $\mathrm{C}=\mathrm{C}$ vibration is IR-inactive in free ethene molecules. However, if the ethene molecule is bonded to $\mathrm{Cu}^{+}$ions, this interaction changes the symmetry of the molecule, and the $\mathrm{C}=\mathrm{C}$ stretching becomes IR-active. The same situation was already observed in our earlier studies of adsorption of ethene $[14,46]$ interacting with $\mathrm{Cu}^{+}$in zeolites CuZSM-5 and CuX. It is interesting to notice that ethene does not polymerize even in the presence of acid sites. It seems that the interaction of $\pi$ electrons of ethene with $\mathrm{Cu}^{+}$ protects the molecule against the attack of protons and formation of carbocation, which is an indispensable step of polymerization. $\mathrm{Cu}^{+}{ }_{\text {exch }}$ does not participate in ethanol oxidation.
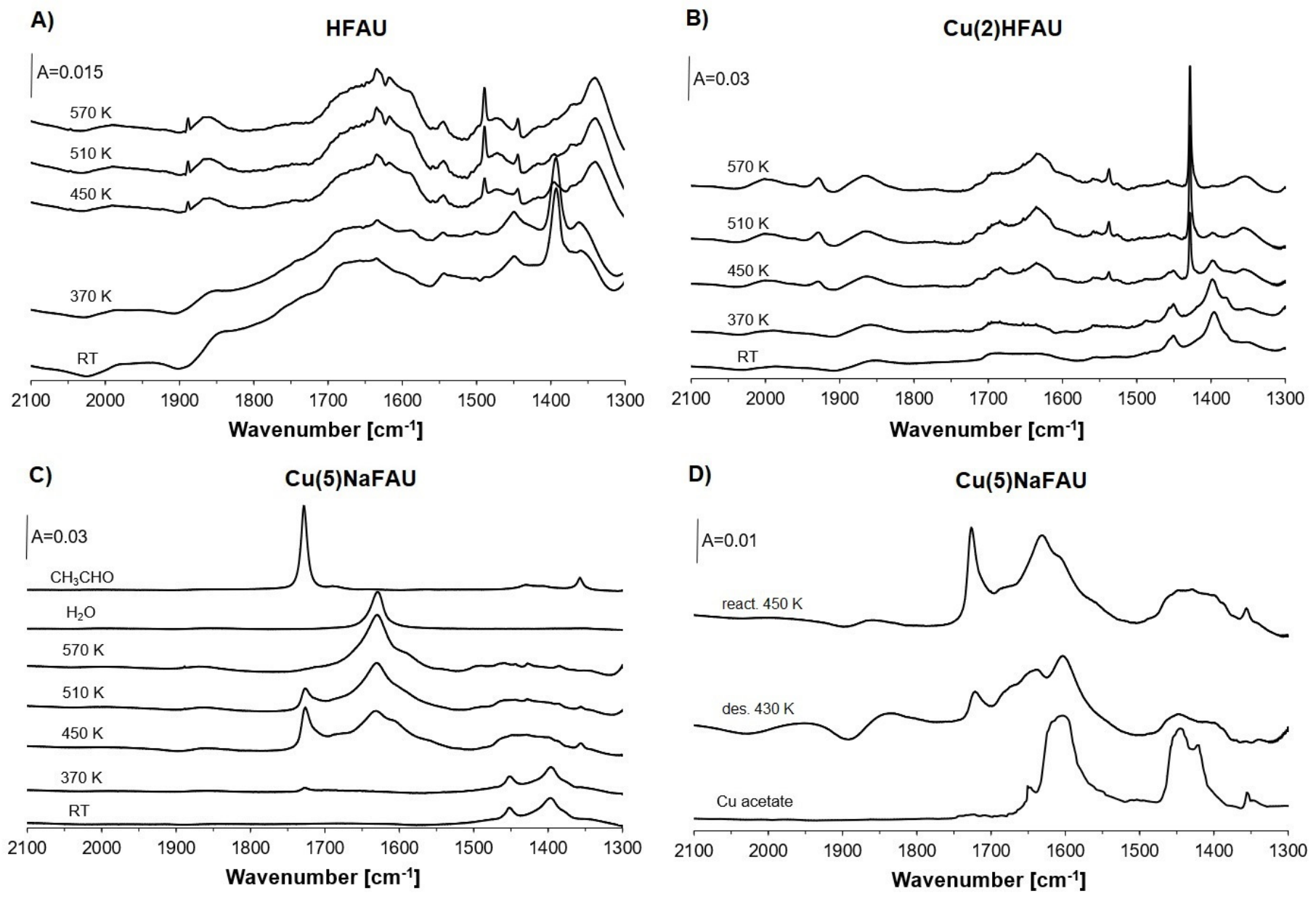

Figure 3. The spectra recorded upon the sorption of ethanol in zeolites HFAU (A), Cu(2)HFAU (B) and Cu(5)NaFAU (C) and heating to $370,450,510$ and $570 \mathrm{~K}$. The spectra recorded upon the reaction of ethanol in $\mathrm{Cu}(5) \mathrm{NaFAU}$ at $450 \mathrm{~K}$ and evacuation at $430 \mathrm{~K}$ are presented in (D).

\subsection{Reaction of Ethanol in $\mathrm{Cu}(5) \mathrm{NaFAU}$}

The $\mathrm{Cu}$ sites in zeolite $\mathrm{Cu}(5) \mathrm{NaFAU}$ are different to those in $\mathrm{Cu}(2) \mathrm{HFAU}$. In the case of $\mathrm{Cu}(2) \mathrm{HFAU}$, a large amount of $\mathrm{Cu}^{+}$exch and a small $\mathrm{Cu}^{2+}$ content are present, while for zeolite $\mathrm{Cu}(5) \mathrm{NaFAU}$, a much smaller amount of $\mathrm{Cu}^{+}$exch and comparable amount of $\mathrm{Cu}^{+}$ox content were detected. Additionally, it contains also high amounts of $\mathrm{Cu}^{2+}$.

The spectra of ethanol sorbed in $\mathrm{Cu}(5) \mathrm{NaFAU}$ at room temperature (Figure 3C) is the same as the spectrum of ethanol sorbed in HFAU and $\mathrm{Cu}(2) \mathrm{HFAU}$ at the same temperature. It shows only the bands of $\mathrm{CH}_{2}$ and $\mathrm{CH}_{3}$ of ethanol. However, new IR bands appear at 
1355,1630 and $1730 \mathrm{~cm}^{-1}$ at higher temperatures. The band at $1630 \mathrm{~cm}^{-1}$ is typical of deformation vibration of water molecule, as evidenced by the fact that the same band is present in the spectrum of water sorbed in our zeolite (Figure 3C). The bands at 1355 and $1730 \mathrm{~cm}^{-1}$ may be attributed to acetaldehyde, because the same bands are present in the spectrum of acetaldehyde sorbed in the same zeolite (Figure 3C). The bands of ethanol (1395 and $1450 \mathrm{~cm}^{-1}$ ) are not present. The presented result evidence that ethanol was oxidized to acetaldehyde at 450 and $510 \mathrm{~K}$ with the formation of water. The spectrum recorded at $450 \mathrm{~K}$ also showed the shoulder at ca. $1600 \mathrm{~cm}^{-1}$. The heating of the zeolite with reactants (ethanol, acetaldehyde and water) to $510 \mathrm{~K}$ caused the decrease in the bands of acetaldehyde with a simultaneous increase in the $1630 \mathrm{~cm}^{-1}$ band of water, evidencing the further reaction of acetaldehyde at higher temperature, in which water was produced. The evacuation at $450 \mathrm{~K}$ (Figure 3D) caused the decrease of the bands of acetaldehyde and water; the bands at 1405, 1450,1605, and $1640 \mathrm{~cm}^{-1}$ of the surface species, which survived evacuation, were present. The spectrum of these stable surface species showed similar IR bands to the spectrum of coper acetate (Figure 3D), suggesting that some acetaldehyde molecules were oxidized to acetic acid, which reacted with $\mathrm{Cu}$-oxides or with the zeolite framework, forming the acetate $\left(\mathrm{CH}_{3} \mathrm{COO}^{-}\right)$species and water. The bands at 1450 and $1605 \mathrm{~cm}^{-1}$ may be due to symmetric and antisymmetric vibrations of the $\mathrm{COO}^{-}$species.

The reactions of the oxidation of ethanol on some oxides and noble metals supported on these oxides were studied by several authors [47-52]. On $\mathrm{CeO}_{2}$ and $\mathrm{ZrO}_{2}$, ethanol formed ethoxy species (by the reaction with surface hydroxyls), which were subsequently oxidized to acetaldehyde and to the acetate species; the same reactions were observed for $\mathrm{CeO}_{2}$ supported metals. For the $\mathrm{CuO} / \mathrm{ZrO}_{2}$ system, three kinds of ethoxy species were found [52]: linear ethoxyls (1100 and $1150 \mathrm{~cm}^{-1} \mathrm{C}-\mathrm{O}$ stretching bands) and bridged ethoxyls $\left(1060 \mathrm{~cm}^{-1}\right)$. At higher temperatures, the ethoxy species produced acetaldehyde and hydrogen (this was found by mass spectrometry). Acetate forms were also produced (IR bands 1440 and $1550 \mathrm{~cm}^{-1}$ ). An interesting observation was the production of acetone, which was the product of condensation. On some metals, such as Pt or Pd supported on $\mathrm{CeO}_{2}$, acetaldehyde was formed, but at higher temperatures, acetaldehyde condensed, forming other organic molecules, such as crotonaldehyde. On the other hand, $\mathrm{CO}$ was formed in the presence of $\mathrm{Rh}$, indicating the power of $\mathrm{Rh}$ in the breaking of the carboncarbon bond in acetaldehyde.

It should be noted that in our study, the oxidation of ethanol and acetaldehyde over zeolite $\mathrm{Cu}(5) \mathrm{NaFAU}$ took place without the supply of molecular oxygen, so the oxygen donors may be the $\mathrm{Cu}$-species present in this zeolite. Zeolite $\mathrm{Cu}(5) \mathrm{NaFAU}$ contains $\mathrm{Cu}^{+}$ox and $\mathrm{Cu}^{2+}{ }_{\text {ox }}(\mathrm{CuO})$. These species may be potential donors of oxygen; however, in the presence of water, $\mathrm{Cu}^{2+}$ exch may also produce $\mathrm{CuO}$ due to hydrolysis and further dehydration of hydroxycations. All these $\mathrm{Cu}$-oxide forms may act as oxygen donors.

\subsection{Oxygen Donors in Ethanol Oxidation}

The information on the role of $\mathrm{Cu}$ species in our zeolite $\mathrm{Cu}(5) \mathrm{NaFAU}$ in ethanol oxidation was obtained in the experiments, in which $\mathrm{CO}$ and $\mathrm{NO}$ were sorbed before and after the reaction of ethanol at $450 \mathrm{~K}$ (Figure $4 \mathrm{~A}, \mathrm{~B}$ ). At this temperature, ethanol is oxidized to acetaldehyde and further to the acetate species (Figure 3C). The CO sorption experiments evidenced that most of $\mathrm{Cu}^{+}$ox (characterized by the $\mathrm{Cu}^{+}{ }_{\text {ox }}-\mathrm{CO}$ band at $2130 \mathrm{~cm}^{-1}$ ) were consumed by the reaction of ethanol at $450 \mathrm{~K}$. Similarly, the reaction with ethanol at the same temperature reduced the amount of $\mathrm{Cu}^{2+}$ (the $\mathrm{Cu}^{2+}$-NO bands $1800-1900 \mathrm{~cm}^{-1}$ decreased). These results evidence that at $450 \mathrm{~K}$, both $\mathrm{Cu}^{+}$ox and $\mathrm{Cu}^{2+}$ species may be donors of oxygen in the oxidation of ethanol, producing acetaldehyde undergoing further oxidation toward the acetate species. 


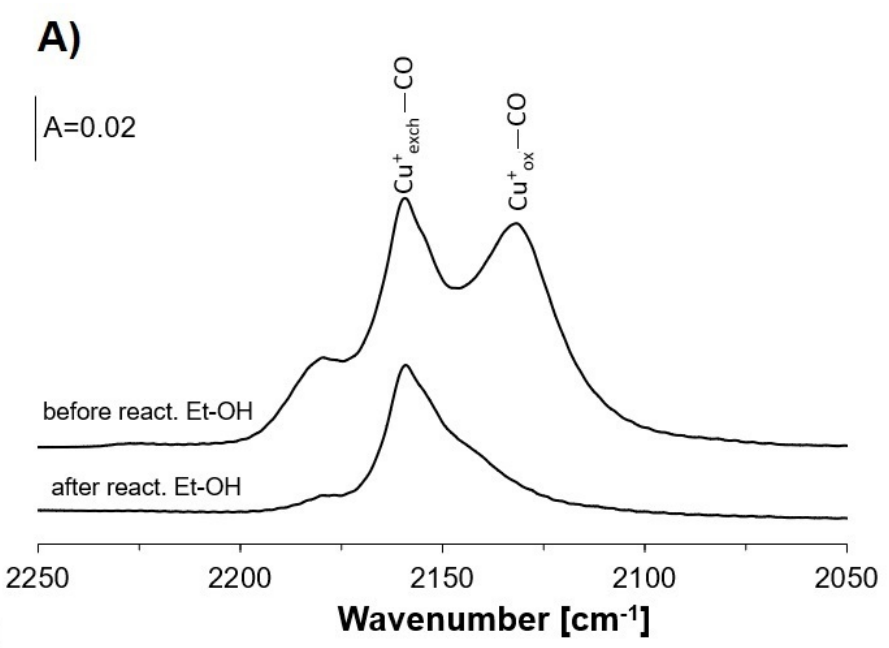

B)

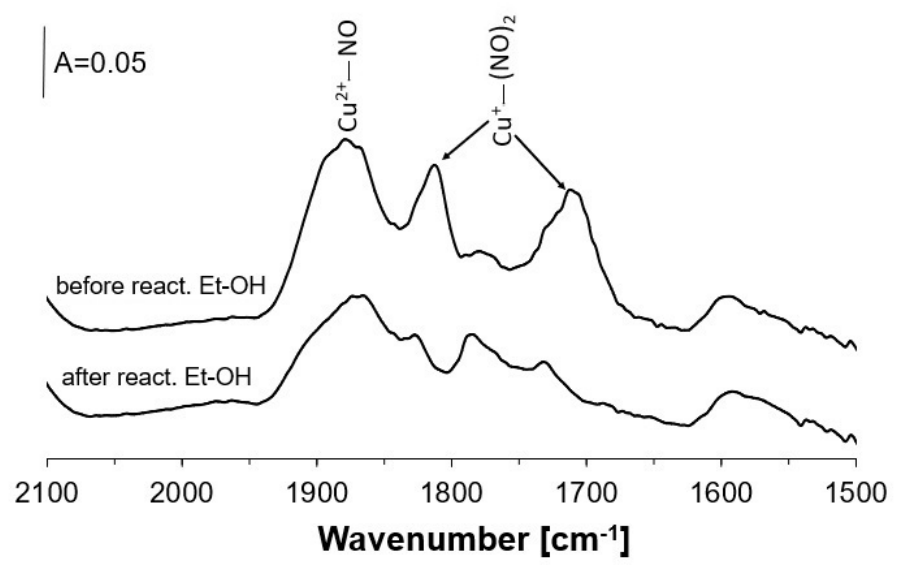

Figure 4. The spectra of $\mathrm{CO}(\mathrm{A})$ and $\mathrm{NO}(\mathrm{B})$ sorbed at room temperature (CO) and at $190 \mathrm{~K}(\mathrm{NO})$ in zeolite $\mathrm{Cu}(5) \mathrm{NaFAU}$ before and after the reaction with ethanol at $450 \mathrm{~K}$.

Further information on the role of $\mathrm{Cu}^{2+}$ and $\mathrm{Cu}^{+}$ox in the oxidation reactions was obtained in the experiments, in which ethanol was sorbed in zeolite of different proportions between $\mathrm{Cu}^{2+}$ and $\mathrm{Cu}^{+}$ox contents. In one series of experiments, zeolite was activated at $720 \mathrm{~K}$, and then oxidized by oxygen treatment at $570 \mathrm{~K}$. In the second one, it was activated at $470 \mathrm{~K}$ instead of $720 \mathrm{~K}$. In turn, in the last series, ethanol was sorbed over zeolite on which the oxidation of ethanol was performed prior to the sorption of ethanol.

In the first series of experiments, zeolite $\mathrm{Cu}(5) \mathrm{NaFAU}$ was oxidized in oxygen at $570 \mathrm{~K}$ and next, evacuated at the same temperature. The IR spectra of $\mathrm{CO}$ sorbed in this zeolite evidenced a decrease in the band of $\mathrm{CO}$ interacting with $\mathrm{Cu}^{+}{ }_{\text {ox }}$ (Figure 5A). The experiments of $\mathrm{NO}$ sorption indicated, in an indirect way, the increase in $\mathrm{Cu}^{2+}$ content (NO band at $1850-1900 \mathrm{~cm}^{-1}$ grows, Figure 5B) compared to non-oxidized zeolite. Therefore, the treatment with oxygen decreased the contribution of $\mathrm{Cu}^{+}{ }_{\text {ox }}$ and increased the amount of $\mathrm{Cu}^{2+}$. The spectra recorded upon the sorption of ethanol at room temperature and heating to $450 \mathrm{~K}$ are presented in Figure $5 \mathrm{C}$ and may be compared with the spectra recorded upon sorption of ethanol in non-oxidized zeolite. The reaction of ethanol in oxidized zeolite produced more acetaldehyde than for the zeolite that was not treated with oxygen. The shoulder at ca. $1600 \mathrm{~cm}^{-1}$ was absent. This result suggests that $\mathrm{Cu}^{2+}$ species are donors of oxygen in the oxidation of ethanol to acetaldehyde, but for further reaction, i.e., oxidation of acetaldehyde to acetate species, $\mathrm{Cu}^{+}{ }_{\text {ox }}$ forms are necessary.

In the second series of experiments, zeolite $\mathrm{Cu}(5) \mathrm{NaFAU}$ was activated in vacuum at $470 \mathrm{~K}$ instead of $720 \mathrm{~K}$. Zeolite activated at $470 \mathrm{~K}$ contains less of both $\mathrm{Cu}^{+}{ }_{\text {ox }}$ and $\mathrm{Cu}^{+}$exch, as well as somewhat more of $\mathrm{Cu}^{2+}$, which was evidenced by low intensities of $\mathrm{Cu}^{+}-\mathrm{CO}$ bands (Figure 5A) and by higher intensity of the $\mathrm{Cu}^{2+}-\mathrm{NO}$ band (Figure $5 \mathrm{~B}$ ), respectively. This observation may be explained by the transformation of $\mathrm{CuO}$ into $\mathrm{Cu}_{2} \mathrm{O}$ at higher temperatures. According to the data presented in Figure 5C, the reaction of ethanol over $\mathrm{Cu}(5) \mathrm{NaFAU}$ activated at $470 \mathrm{~K}$ produced more acetaldehyde than over the catalyst activated at $720 \mathrm{~K}$, and did not produce acetate species. It again confirms the importance of $\mathrm{Cu}^{+}{ }_{\text {ox }}$ in the oxidation of acetaldehyde to acetates.

The third series of experiments was the reaction of ethanol over zeolite $\mathrm{Cu}(5) \mathrm{NaFAU}$, in which the oxidation of ethanol was already done. In these experiments, ethanol was adsorbed in freshly activated zeolite, and upon heating to $450 \mathrm{~K}$ and subsequent evacuation at $570 \mathrm{~K}$, the zeolite was cooled to room temperature. Ethanol was again adsorbed at room temperature, subsequently, and heated to $450 \mathrm{~K}$. The spectrum recorded upon heating to $450 \mathrm{~K}$; subsequent cooling to room temperature (Figure 5C) shows the band of acetaldehyde $\left(1730 \mathrm{~cm}^{-1}\right)$, but the shoulder at ca. $1600 \mathrm{~cm}^{-1}$, typical of the acetate species, is absent. The experiments of $\mathrm{CO}$ and $\mathrm{NO}$ sorption (Figure 5A,B) evidenced the decrease in the 
amount of both $\mathrm{Cu}^{+}$ox and $\mathrm{Cu}^{2+}$. These results evidence that the oxidation of ethanol and the production of acetaldehyde and the acetate species consumes some $\mathrm{Cu}^{2+}$ and most of the $\mathrm{Cu}^{+}{ }_{\text {ox }}$. In turn, the reaction of ethanol on such treated zeolite (Figure 5C) produces acetaldehyde without the acetate species (Figure 5C). The results obtained in all these three series of experiments suggested that $\mathrm{Cu}^{2+}$ species (most probable $\mathrm{CuO}$ ) are oxygen donors in ethanol oxidation to acetaldehyde, and $\mathrm{Cu}^{+}$ox species are responsible for acetate formation.
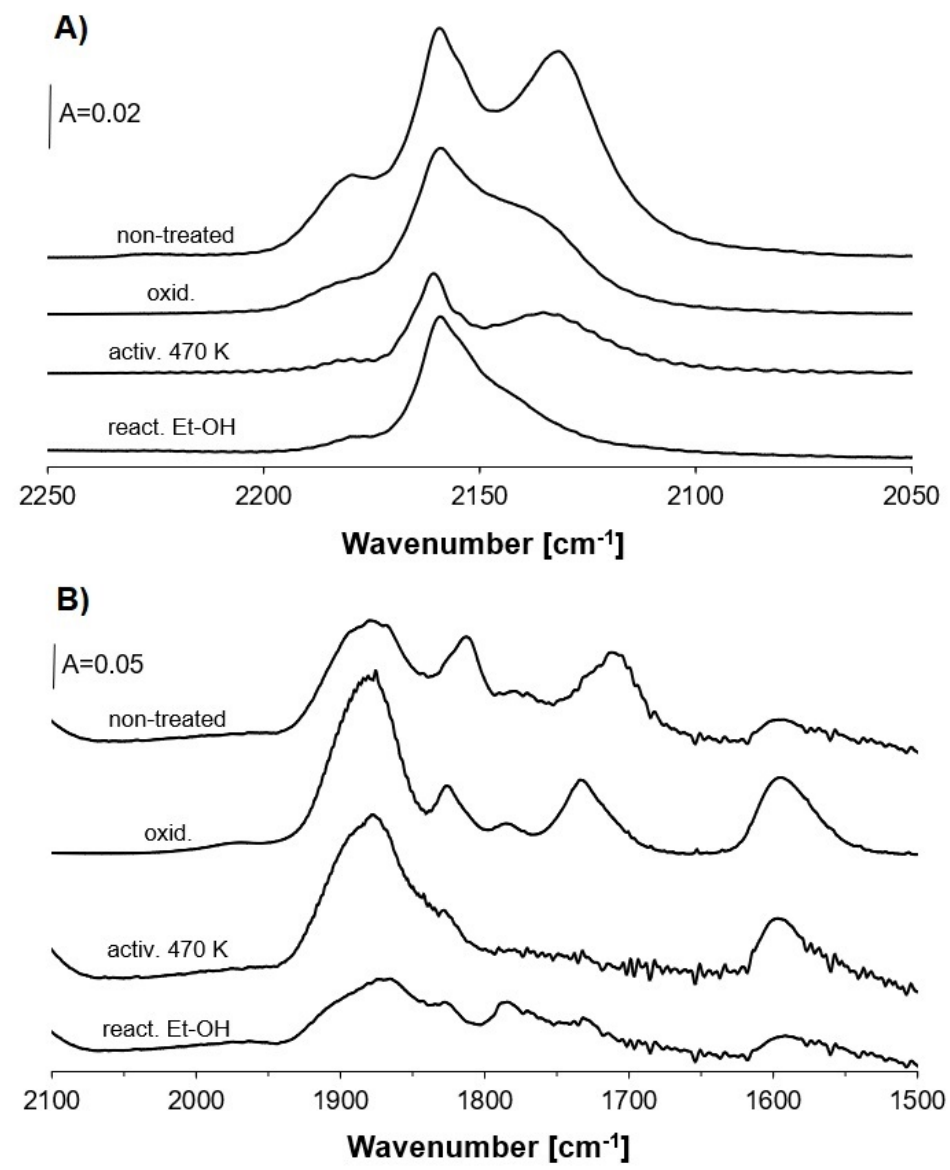

C)

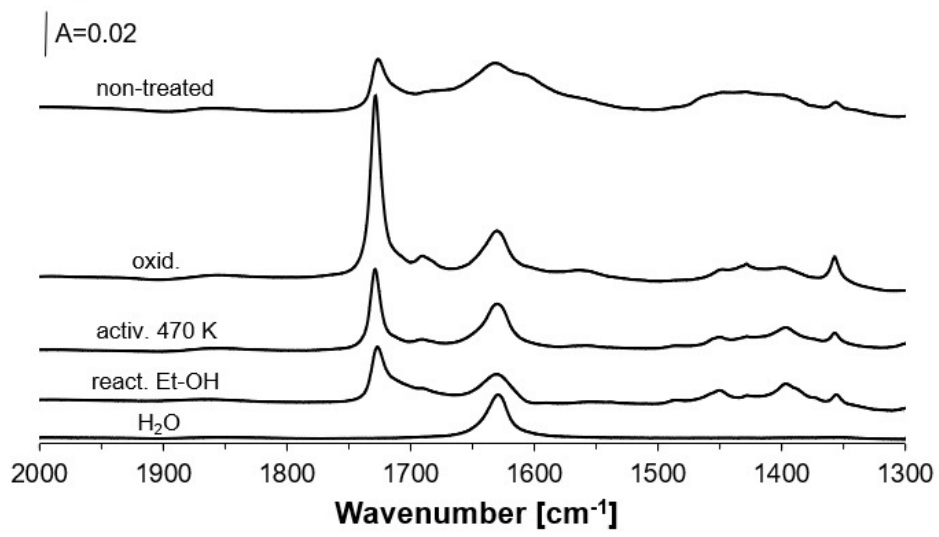

Figure 5. The spectra of CO sorbed at room temperature (A), NO sorbed at $190 \mathrm{~K}$ (B) and the spectra recorded upon sorption of ethanol and heating to $450 \mathrm{~K}(\mathrm{C})$ in zeolite $\mathrm{Cu}(5) \mathrm{NaFAU}$ non treated, the same zeolite oxidized, zeolite activated at $470 \mathrm{~K}$ as well as zeolite in which the reaction of ethanol was carried out. The spectrum of water sorbed in zeolite is also presented. 
The information on the role of $\mathrm{Cu}$ species in ethanol oxidation was also obtained in the experiments, in which ethanol was adsorbed on bulk $\mathrm{CuO}$ and $\mathrm{Cu}_{2} \mathrm{O}$ mixed with $\mathrm{SiO}_{2}$ and heated to $370,450,510$ and $570 \mathrm{~K}$.

The information on the presence of $\mathrm{Cu}$ sites was obtained by the adsorption of $\mathrm{CO}$ and $\mathrm{NO}$ as probe molecules (Figure 6). The presence of $\mathrm{Cu}^{+}$and $\mathrm{Cu}^{2+}$ on the surfaces of both oxides was found. The concentration of $\mathrm{Cu}^{+}$was higher on $\mathrm{Cu}_{2} \mathrm{O}$; meanwhile, for $\mathrm{CuO}$, the contribution of $\mathrm{Cu}^{2+}$ was dominating.

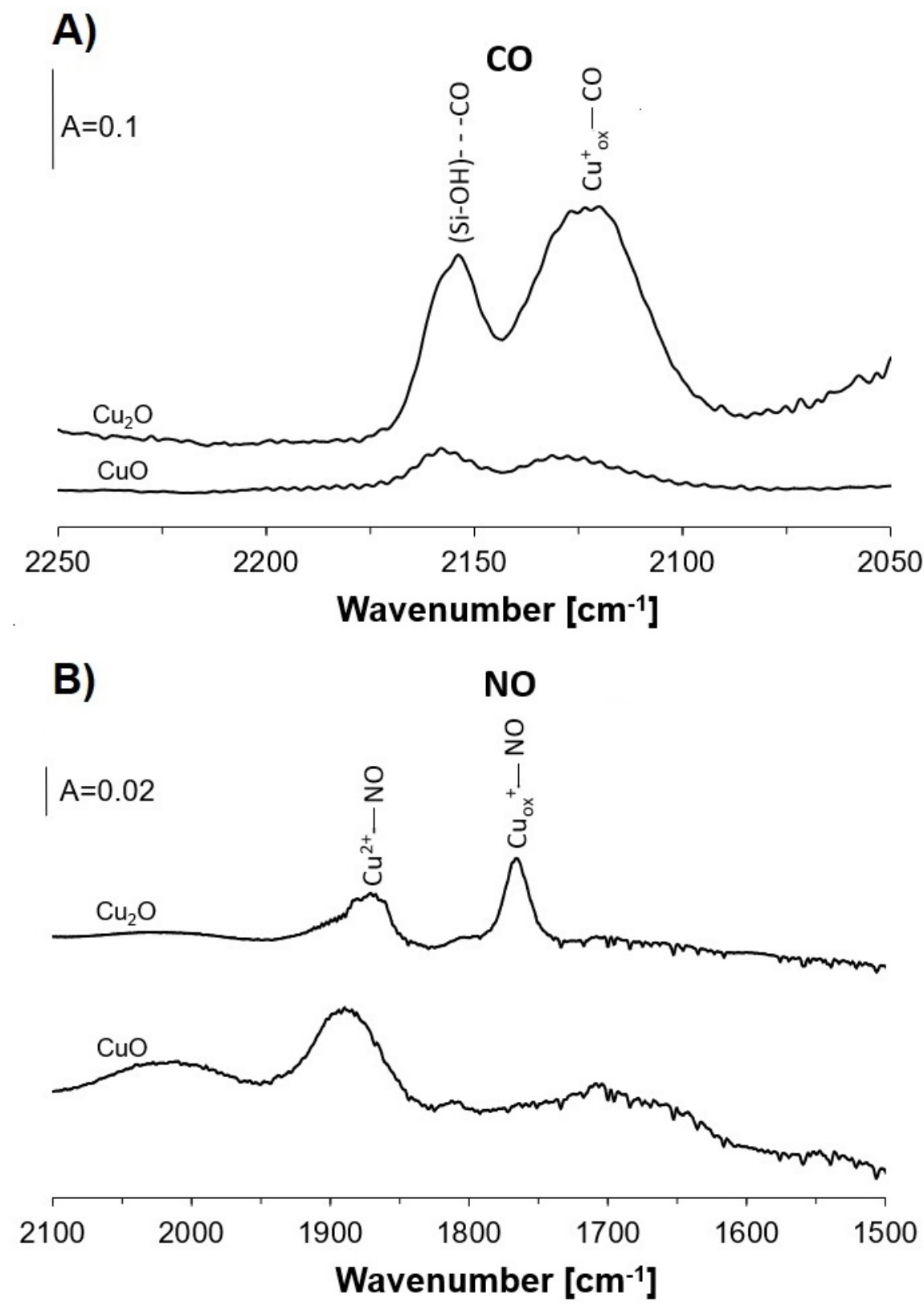

Figure 6. IR spectra of $\mathrm{CO}(\mathrm{A})$ and $\mathrm{NO}(\mathbf{B})$ adsorbed at $170 \mathrm{~K}$ on $\mathrm{Cu}_{2} \mathrm{O}$ and $\mathrm{CuO}$ diluted in $\mathrm{SiO}_{2}$.

The spectra recorded upon ethanol adsorption and heating to higher temperatures are presented in Figure 7A,B. The spectra of ethanol recorded at room temperature on both oxides are the same as in the case of ethanol sorbed in zeolites (Figure 3C). Heating to $370 \mathrm{~K}$ did not produce acetaldehyde, but small amounts of acetaldehyde were formed at $450 \mathrm{~K}$. In the case of $\mathrm{CuO}$, the amount of acetaldehyde attained a maximum at $510 \mathrm{~K}$; the amount decreased at $570 \mathrm{~K}$ due to oxidation of acetaldehyde with the formation of water (band at $1630 \mathrm{~cm}^{-1}$ ), as well as $\mathrm{CO}$ and $\mathrm{CO}_{2}$ (spectra not shown). The small loss of acetaldehyde is 
well seen in the difference spectrum (top spectrum in Figure 7A). The situation is different for $\mathrm{Cu}_{2} \mathrm{O}$ (Figure $7 \mathrm{~B}$ ), in which heating to $570 \mathrm{~K}$ produced acetic acid. It may be supposed that acetic acid was also formed in the reaction of ethanol on zeolite $\mathrm{Cu}(5) \mathrm{NaFAU}$, but acid reacted with zeolite and formed the acetate species. The reaction of acetic acid in zeolites producing acetate ions was already observed [53].
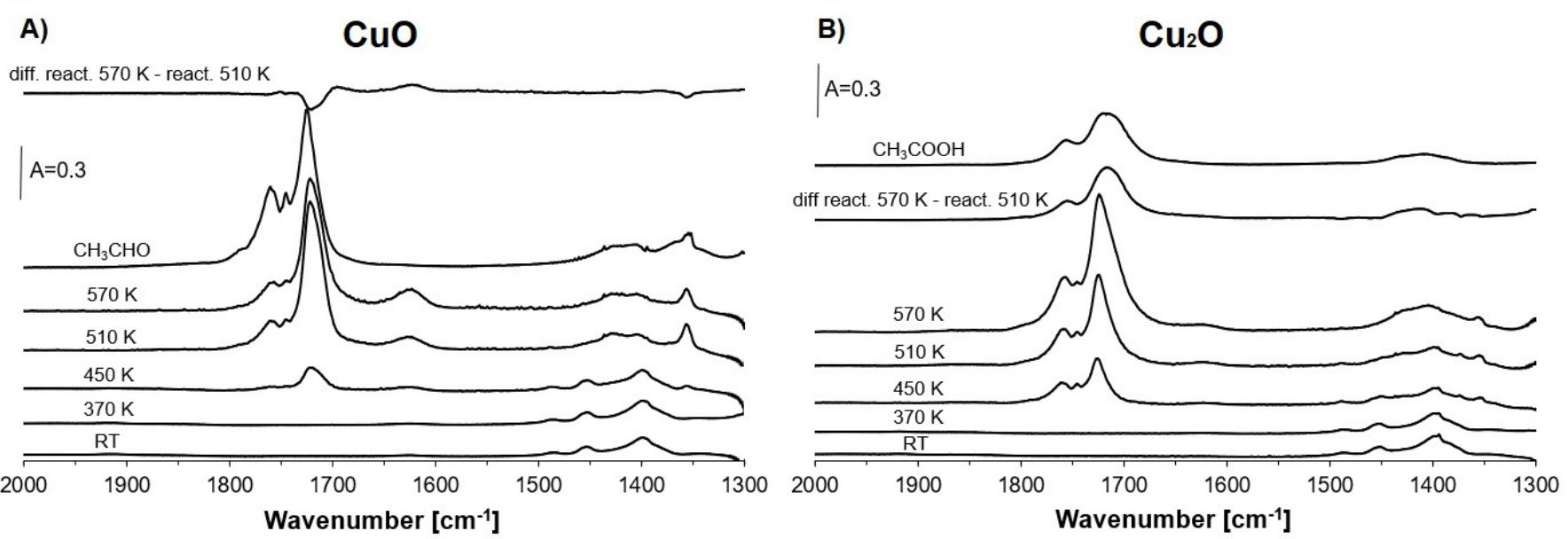

Figure 7. The spectra recorded upon the adsorption of ethanol on $\mathrm{CuO} / \mathrm{SiO}_{2}(\mathbf{A})$ and on $\mathrm{Cu} \mathrm{O}_{2} \mathrm{O} / \mathrm{SiO}_{2}(\mathbf{B})$ at room temperature and heating to $370,450,510$ and $570 \mathrm{~K}$ as well as the differences between the spectra recorded upon the heating to $570 \mathrm{~K}$ and $510 \mathrm{~K}$. The spectra of acetaldehyde and acetic acid are also presented.

The difference spectrum (between spectra recorded upon heating to 570 and $510 \mathrm{~K}$ ) is very similar to the spectrum of acetic acid adsorbed on $\mathrm{SiO}$. It should be noted that acetic acid was not formed for $\mathrm{CuO}$ (Figure 7A).

Generally, it can be postulated that $\mathrm{Cu}^{2+}($ mostly $\mathrm{CuO})$ is a donor of oxygen in the oxidation of ethanol to acetaldehyde; however, $\mathrm{Cu}^{+}$ox is responsible for the oxygen supply in further oxidation of acetaldehyde to acetic acid (or acetate species). Unfortunately, the role of $\mathrm{Cu}^{+}{ }_{\text {ox }}$ in the oxidation of ethanol to acetaldehyde cannot be evidenced due to the impossibility of the investigation of this reaction on materials containing only $\mathrm{Cu}^{+}{ }_{\text {ox }}$. Neither zeolite nor $\mathrm{Cu}_{2} \mathrm{O}$ containing only $\mathrm{Cu}^{+}$ox without $\mathrm{Cu}^{2+}$ can be obtained. $\mathrm{Bulk} \mathrm{Cu}_{2} \mathrm{O}$ always contains some $\mathrm{Cu}^{2+}$ produced by the contact with atmospheric air (Figure $6 \mathrm{~B}$ ). The $\mathrm{CuO}$ and $\mathrm{Cu}_{2} \mathrm{O}$ particles may be situated inside zeolitic channels and pores or can be present on external surfaces of zeolite crystals.

The role of oxygen-containing $\mathrm{Cu}$ species as oxygen donors in the oxidation of benzyl alcohol to benzaldehyde, $\mathrm{CO}$ and $\mathrm{CO}_{2}$ on Cu-ZSM-5 zeolite was studied by Nakao et al. [24]. Catalytic performance results were completed with the IR studies of $\mathrm{CO}$ and benzaldehyde sorption. An interesting observation was the formation of relatively small amounts of benzaldehyde even in the absence of gaseous oxygen, suggesting that oxygen-containing $\mathrm{Cu}$ species were a source of oxygen in the reaction. IR spectra of CO sorbed on CuZSM-5 zeolites showed the bands at 2156 and $2135 \mathrm{~cm}^{-1}$, which can be assigned to $\mathrm{Cu}^{+}{ }_{\text {exch- }}-\mathrm{CO}$ and $\mathrm{Cu}^{+}{ }_{\text {ox }}-\mathrm{CO}$, respectively. The authors indicated that the $\mathrm{Cu}^{2+}$ and $\mathrm{Cu}^{2+}-\mathrm{O}_{2}$ adducts reacted with benzyl alcohol, producing benzaldehyde and $\mathrm{Cu}^{+}$, which was subsequently reoxidized with molecular oxygen. The results obtained in our study are consistent with the conclusions of Nakao et al. [24].

\section{Materials and Methods}

\subsection{Materials}

Pristine zeolite of faujasite-type structure denoted as HFAU $(\mathrm{Si} / \mathrm{Al}=31)$ was produced by Zeolyst company (CBV 760). It was dealuminated by steaming and acid treatment by the producer. $\mathrm{Cu}$-containing zeolites $\mathrm{Cu}(2) \mathrm{HFAU}$ and $\mathrm{Cu}(5) \mathrm{NaFAU}$ were obtained by the impregnation method with $0.5 \mathrm{M} \mathrm{Cu}\left(\mathrm{NO}_{3}\right)_{2}$ solution. The amounts of $\mathrm{Cu}$ ions in solutions 
corresponded to $2 \%$ or $5 \%$ of $\mathrm{Cu}$ in impregnated zeolites. Zeolite $\mathrm{Cu}(2) \mathrm{HFAU}$ was obtained by the impregnation of pristine HFAU. It contained $2 \mathrm{wt} . \%$ of $\mathrm{Cu}$. In order to obtain $\mathrm{Cu}(5) \mathrm{NaFAU}$, zeolite HFAU was transformed into sodium form by four-fold exchange with $0.5 \mathrm{M} \mathrm{NaNO}_{3}$, and then washed in distilled water. The resulting NaFAU was subsequently impregnated with $0.5 \mathrm{M} \mathrm{Cu}\left(\mathrm{NO}_{3}\right)_{2}$, producing zeolite containing $5 \mathrm{wt}$.\% of $\mathrm{Cu}$. All samples were dried at $390 \mathrm{~K}$ and next calcined at $770 \mathrm{~K}$.

Bulk $\mathrm{CuO}$ and $\mathrm{Cu}_{2} \mathrm{O}$ (Aldrich) were used in the IR measurements. Both oxides were mixed with $\mathrm{SiO}_{2}$ Cabosil in proportion with 8 wt.\% of oxides, and 92 wt.\% of SiOEthanol, acetaldehyde and acetic acid (Aldrich) were used in IR adsorption experiments.

\subsection{IR Studies}

In most cases, prior to the IR experiments, zeolites were evacuated in situ in an IR cell at $720 \mathrm{~K}$ for $1 \mathrm{~h}$. The $\mathrm{CuO} / \mathrm{SiO}_{2}$ and $\mathrm{Cu}_{2} \mathrm{O} / \mathrm{SiO}_{2}$ wafers were evacuated at $470 \mathrm{~K}$ and $710 \mathrm{~K}$, respectively, for $1 \mathrm{~h}$. In some experiments, zeolite $\mathrm{Cu}(5) \mathrm{NaFAU}$ was pretreated in vacuum at $720 \mathrm{~K}$, then subsequently treated with oxygen at $570 \mathrm{~K}$ for $1 \mathrm{~h}$ and finally, evacuated at the same temperature.

The spectra were recorded with a NICOLET 6700 spectrometer (Thermo Scientific, Cambridge, MA, USA) with the spectral resolution of $1 \mathrm{~cm}^{-} \mathrm{CO}$, and NO (Air Products) were used as probe molecules. The adsorption of $\mathrm{CO}$ was performed at room temperature. Adsorption of NO was done at ca. $190 \mathrm{~K}$.

\section{Conclusions}

The coadsorption of ethanol and $\mathrm{CO}$ evidenced the transfer of electrons from ethanol to $\mathrm{Cu}^{+}$and to molecules bonded to the same $\mathrm{Cu}$ ion as $\mathrm{CO}$. Ethanol adsorbed on zeolite HFAU underwent dehydration toward ethane, which polymerized. Dehydration of ethanol also took place on zeolite $\mathrm{Cu}(2) \mathrm{HFAU}$, containing protonic sites and $\mathrm{Cu}^{+}$exch, but in this case, ethene was bonded to $\mathrm{Cu}^{+}$and did not polymerize. The $\mathrm{C}=\mathrm{C}$ stretching, which is IR-inactive in free molecule, became active when ethene interacted with $\mathrm{Cu}^{+}$. Ethanol adsorbed on $\mathrm{Cu}(5) \mathrm{NaFAU}$ containing mostly $\mathrm{Cu}^{+}{ }_{\text {ox }}, \mathrm{Cu}^{2+}$ exch and $\mathrm{Cu}^{2+}$ ox $(\mathrm{CuO})$ was oxidized to acetaldehyde, and further to the acetate species. As oxygen was not supplied, the donors of oxygen in the considered reaction could be oxides of $\mathrm{Cu}^{+}$and $\mathrm{Cu}^{2+}$. In order to learn the role of these copper species in this type of reaction, the $\mathrm{CO}$ and NO sorption in $\mathrm{Cu}$-zeolite before and after ethanol oxidation were carried out. Moreover, the oxidation of ethanol was performed on zeolites, in which the proportion between the amounts of $\mathrm{Cu}^{+}$ox and $\mathrm{Cu}^{2+}$ ox was changed by various treatments. Based on all these experiments, as well as the reaction of ethanol over bulk $\mathrm{CuO}$ and $\mathrm{Cu}_{2} \mathrm{O}$, it may be concluded that ethanol was oxidized to acetaldehyde by $\mathrm{Cu}^{2+}$ ox and probably also by $\mathrm{Cu}^{+}{ }_{\text {ox }}$, whereas $\mathrm{Cu}^{+}{ }_{\text {ox }}$ was responsible for the further oxidation of acetaldehyde to the acetate species.

Author Contributions: Conceptualization, J.D.; methodology, Ł.K.; J.P. and J.D.; software, Ł.K.; validation, J.P. and J.D.; formal analysis, Ł.K.; J.P. and J.D.; investigation, J.P. and J.D.; data curation, Ł.K.; writing—original draft preparation, J.D.; writing—review and editing, Ł.K. and J.D.; visualization, Ł.K.; supervision, J.D. All authors have read and agreed to the published version of the manuscript.

Funding: The research was done within the statutory funds of the Jerzy Haber Institute of Catalysis and Surface Chemistry, Polish Academy of Sciences.

Institutional Review Board Statement: Not applicable.

Informed Consent Statement: Not applicable.

Data Availability Statement: Not applicable.

Conflicts of Interest: The authors declare no conflict of interest.

Sample Availability: Samples of the compounds of $\mathrm{Cu}$ containing zeolites of FAU type structure are available from the authors. 


\section{References}

1. Iwamoto, M.; Furukawa, H.; Mine, Y.; Uemura, F.; Mikuriya, S.; Kagawa, S. Copper(II) ion-exchanged ZSM-5 zeolites as highly active catalysts for direct and continuous decomposition of nitrogen monoxide. J. Chem. Soc. Chem. Commun. 1986, 16, 1272-1273. [CrossRef]

2. Iwamoto, M.; Yokoo, S.; Sakai, K.; Kagawa, S. Catalytic decomposition of nitric oxide over copper(II)-exchanged, Y-type zeolites. J. Chem. Soc. Faraday Trans. 1981, 77, 1629-1638. [CrossRef]

3. Spoto, G.; Zecchina, A.; Bordiga, S.; Ricchiardi, G.; Martra, G.; Leofanti, G.; Petrini, G. Cu(I)-ZSM-5 zeolites prepared by reaction of H-ZSM-5 with gaseous $\mathrm{CuCl}$ : Spectroscopic characterization and reactivity towards carbon monoxide and nitric oxide. Appl. Catal. B 1994, 3, 151-172. [CrossRef]

4. Mizumoto, M.; Yamazoe, N.; Seiyama, T. Efects of coexisting gases on the catalytic reduction of $\mathrm{NO}_{\text {with }} \mathrm{NH}_{3}$ over $\mathrm{Cu}(\mathrm{II}) \mathrm{Na}$ Y. J. Catal. 1979, 59, 319-324. [CrossRef]

5. Wichterlová, B.; Sobalík, Z.; Skokánek, M. Effect of water vapour and ammonia on the solid-solid interaction of Cu oxide with Y-type zeolite: Preparation of catalyst for reduction of nitric oxide with ammonia at low temperature. Appl. Catal. A 1993, 103, 269-280. [CrossRef]

6. Petunchi, O.; Sill, G.; Hall, W.K. Studies of the selective reduction of nitric oxide by hydrocarbons. Appl. Catal. B 1993, 2, 303-321. [CrossRef]

7. Burch, R.; Scire, S. Selective catalytic reduction of nitric oxide with ethane and methane on some metal exchanged ZSM-5 zeolites. Appl. Catal. B 1994, 3, 295-318. [CrossRef]

8. Kucherov, A.V.; Gerlock, J.L.; Jen, H.W.; Shelef, M. In Situ ESR Monitoring of CuH-ZSM-5 Up to $500^{\circ} \mathrm{C}$ in Flowing Dry Mixtures of $\mathrm{No}\left(\mathrm{NO}_{2}\right), \mathrm{C}_{3} \mathrm{H}_{6}\left(\mathrm{C}_{2} \mathrm{H}_{5} \mathrm{OH}\right)$, and Excess O. J. Catal. 1995, 152, 63-69. [CrossRef]

9. Choi, E.Y.; Nam, I.S.; Kim, Y.G. TPD Study of Mordenite-Type Zeolites for Selective Catalytic Reduction of NO by NH. J. Catal. 1996, 161, 597-604. [CrossRef]

10. Broclawik, E.; Datka, J.; Gil, B.; Kozyra, P. Why Cu ${ }^{+}$in ZSM-5 framework is active in DeNOx reaction-Quantum chemical calculations and IR studies. Catal. Today 2002, 75, 353-357. [CrossRef]

11. Rejmak, P.; Broclawik, E.; Góra-Marek, K.; Radoń, M.; Datka, J. Nitrogen Monoxide Interaction with Cu(I) Sites in Zeolites X and Y: Quantum Chemical Calculations and IR Studies. J. Phys. Chem. C 2008, 112, 17998-18010. [CrossRef]

12. Hessou, E.P.; Kanhounnon, W.G.; Rocca, D.; Monnier, H.; Vallières, C.; Lebègue, S.; Badawi, M. Adsorption of $\mathrm{NO} \mathrm{NO}_{2}$, $\mathrm{CO}, \mathrm{H}_{2} \mathrm{O}$ and $\mathrm{CO}_{2}$ over isolated monovalent cations in faujasite zeolite: A periodic DFT investigation. Theor. Chem. Acc. 2018, 137, 161. [CrossRef]

13. Broclawik, E.; Datka, J.; Gil, B.; Kozyra, P. Molecular modelling of copper sites in ZSM-5: DFT and IR studies on the properties of $\mathrm{Cu}^{2+}$ and $\mathrm{Cu}^{+}$Centres and their interaction with NO. Metal-Ligand Interact. 2003, 116, 371-384. [CrossRef]

14. Datka, J.; Kukulska-Zajacc, E. IR Studies of the Activation of CC Bond in Alkenes by $\mathrm{Cu}^{+}$Ions in Zeolites. J. Phys. Chem. B 2004, 108, 17760-17766. [CrossRef]

15. Datka, J.; Kukulska-Zając, E.; Kobyzewa, W. The activation of acetylene by $\mathrm{Cu}^{+}$ions in zeolites studied by IR spectroscopy. Catal. Today 2005, 101, 123-129. [CrossRef]

16. Datka, J.; Kozyra, P.; Kukulska-Zając, E.; Kobyzewa, W. The activation of CO bond in acetone by Cu ${ }^{+}$cations in zeolites: IR studies and quantum chemical DFT calculations. Catal. Today 2005, 101, 117-122. [CrossRef]

17. Kukulska-Zając, E.; Datka, J. Transformations of Formaldehyde Molecules in Cu-ZSM-5 Zeolites. J. Phys. Chem. 2007, 111, 3471. [CrossRef]

18. Kukulska-Zając, E.; Kozyra, P.; Datka, J. The interaction of benzene with $\mathrm{Cu}^{+}$sites in zeolites: IR studies and DFT quantum chemical calculations. Appl. Catal. A 2006, 307, 46-50. [CrossRef]

19. Hübner, G.; Rauhut, G.; Stoll, H. FTIR measurements and quantum chemical calculations of ethylene adsorbed on CuNaY. Phys. Chem. Chem. Phys. 2002, 4, 3112-3121. [CrossRef]

20. Hübner, G.; Rauhut, G.; Stoll, H.; Roduner, E. Ethyne Adsorbed on CuNaY Zeolite: FTIR Spectra and Quantum Chemical Calculations. J. Phys Chem. B 2003, 107, 8568-8573. [CrossRef]

21. Tsuruya, S.; Okamoto, Y.; Kuwada, T. Benzyl alcohol oxidation over Y-type zeolite ion-exchanged with copper(II) ion. J. Catal. 1979, 56, 52-64. [CrossRef]

22. Tsuruya, S.; Tsukamoto, M.; Watanabe, M.; Masai, M. Ethanol oxidation over Y-type zeolite ion-exchanged with copper(II) and cobalt(II) ions. J. Catal. 1985, 3, 303-311. [CrossRef]

23. Bun, S.; Nishiyama, S.; Tsuruya, S.; Masai, M. Ethanol conversion over ion-exchanged ZSM-5 zeolites. Appl. Catal. 1990, 59, 13-29. [CrossRef]

24. Nakao, M.; Nishiyama, S.; Tsuruya, S.; Masai, M. Catalysis of copper(II)-NaZSM-5 zeolites during benzyl alcohol oxidation. Inorg. Chem. 1992, 31, 4662-4668. [CrossRef]

25. Sueto, S.; Nishiyama, S.; Tsuruya, S.; Masai, M. Catalytic activity of NaZSM-5 supported Cu catalysts with or without added alkali metal in benzyl alcohol oxidation. J. Chem. Soc. Faraday Trans. 1997, 93, 659-664. [CrossRef]

26. Azizi, S.N.; Tilami, S.E. Cu-modified analcime as a catalyst for oxidation of benzyl alcohol: Experimental and theoretical. Microporous Mesoporous Mater. 2013, 167, 89-93. [CrossRef]

27. Xu, J.; Ekblad, M.; Nishiyama, S.; Tsuruya, S.; Masai, M. Effect of alkali metals added to Cu ion-exchanged Y-type zeolite catalysts in the gas-phase catalytic oxidation of benzyl alcohol. J. Chem. Soc. Faraday Trans. 1998, 94, 473-479. [CrossRef] 
28. Konda, T.; Nishiyama, S.; Tsuruya, S. Infuence and role of added alkali metals on the gas-phase oxidation of benzyl alcohol catalyzed by $\mathrm{Cu}$ ion-exchanged NaX zeolites. Phys. Chem. Chem. Phys. 1999, 1, 5393-5399. [CrossRef]

29. Bhagya, K.N.; Gayathri, V. Metal complexes of 2-methylimidazole encapsulated in zeolite-Y as efficient and reusable catalysts for oxidation of phenol and benzyl alcohol. J. Porous Mater. 2013, 20, 257-266. [CrossRef]

30. Itho, Y.; Nishiyama, S.; Tsuruya, S.; Masai, M. Redox Behavior and Mobility of Copper Ions in NaZSM-5 Zeolite during Oxidation. Phys. Chem. 1994, 98, 960-967. [CrossRef]

31. Mobinikhaledi, A.; Zendehdel, M.; Safari, P. Synthesis and characterization of some novel transition metal Schiff base complexes encapsulated in zeolite Y: Effective catalysts for the selective oxidation of benzyl alcohol. React. Kinet. Mech. Cat. 2013, 110, 497-514. [CrossRef]

32. Hayashibara, H.; Nishiyama, S.; Tsuruya, S.; Masai, M. The Effect of Alkali Promoters on Cu-Na-ZSM-5 Catalysts in the Oxidation of Benzyl Alcohol. J. Catal. 1995, 153, 254-264. [CrossRef]

33. Li, F.; Hu, D.; Yuan, Y.; Luo, B.; Song, Y.; Xiao, S.; Chen, G.; Fang, Y.; Lu, F. Zeolite Y encapsulated Cu (II) and Zn (II)-imidazolesalen catalysts for benzyl alcohol oxidation. Mol. Catal. 2018, 452, 75-82. [CrossRef]

34. Xavier, K.O.; Chacko, J.; Yusuff, K.K.M. Zeolite-encapsulated Co(II), Ni(II) and Cu(II) complexes as catalysts for partial oxidation of benzyl alcohol and ethylbenzene. Appl. Catal. A Gen. 2004, 258, 251-259. [CrossRef]

35. Hu, W.; Li, D.; Yang, Y.; Li, T.; Chen, H.; Liu, P. Copper ferrite supported gold nanoparticles as efficient and recyclable catalyst for liquid-phase ethanol oxidation. J. Catal. 2018, 357, 108-117. [CrossRef]

36. Mirzai, J.I.; Nadirov, P.A.; Velieva, A.D.; Muradkhanli, V.G. Oxidation of Ethanol on NaX Zeolite Modified with Transition Metals. Russ. J. Phys. Chem. A 2017, 91, 1005-1009. [CrossRef]

37. Ahmad, J.U. Copper Catalysts for Alcohol Oxidation. Ph.D. Thesis, the Faculty of Science of the University of Helsinki, Yliopistonkatu, Helsinki, 2012.

38. Janas, J.; Gurgul, J.; Socha, R.P.; Dzwigaj, S. Effect of Cu content on the catalytic activity of CuSiBEA zeolite in the SCR of NO by ethanol: Nature of the copper species. Appl. Catal. B Environ. 2009, 91, 217-224. [CrossRef]

39. Kuterasiński, Ł.; Podobiński, J.; Rutkowska-Zbik, D.; Datka, J. IR Studies of the Cu ions in Cu-Faujasites. Molecules 2019, $24,4250$. [CrossRef] [PubMed]

40. Kuterasiński, Ł.; Podobiński, J.; Madej, E.; Smoliło-Utrata, M.; Rutkowska-Zbik, D.; Datka, J. Reduction and Oxidation of Cu Species in Cu-faujasites Studied by IR Spectroscopy. Molecules 2020, 25, 4765. [CrossRef] [PubMed]

41. Iwamoto, M.; Yahiro, H.; Tanada, K.; Mizumo, N.; Mine, Y.; Kagawa, S. Removal of nitrogen monoxide through a novel catalytic process. Decomposition on excessively copper-ion-exchanged ZSM-5 zeolites. J. Phys. Chem. 1991, 95, 3727. [CrossRef]

42. Tranquada, J.M.; Heald, S.M.; Moodenbaugh, A.R. X-ray-absorption near-edge-structure study of $\mathrm{La}_{2-\mathrm{x}}\left(\mathrm{Ba}_{3} \mathrm{Sr}\right)_{\mathrm{x}} \mathrm{CuO} \mathrm{O}_{4-\mathrm{y}} \mathrm{super}_{-}$ conductors. Phys. Rev. B 1987, 36, 5263. [CrossRef] [PubMed]

43. Lamberti, C.; Bordiga, S.; Salvalaggio, M.; Sopto, G.; Zecchina, A. XAFS, IR, and UV-Vis Study of the Cu ${ }^{\mathrm{I}}$ Environment in Cu ${ }^{\mathrm{I}-Z S M-5 . ~ J . ~ P h y s . ~ C h e m . ~ B ~ 1997, ~ 101, ~ 344-360 . ~[C r o s s R e f] ~}$

44. Datka, J.; Kukulska-Zając, E.; Kobyzewa, W. IR Studies of Co-adsorption of Organic Molecules and CO on Cu+ Cations in Zeolites. Catal. Today 2006, 114, 169-173. [CrossRef]

45. Gulmine, J.V.; Janissek, P.R.; Heisse, H.M.; Akcelrud, L. Polyethylene Characterization by FTIR. Polym. Test. 2002, $21,557-563$. [CrossRef]

46. Kozyra, P.; Góra-Marek, K.; Datka, J. Extinction coefficients of $\mathrm{C}=\mathrm{C}$ and $\mathrm{C} \equiv \mathrm{C}$ bands in Ethene and Ethyne Molecules Interacting with $\mathrm{Cu}^{+}$and $\mathrm{Ag}^{+}$in zeolites-IR studies and quantumchemical calculations. Spectrochim. Acta A 2014, 136, 1988-1992. [CrossRef] [PubMed]

47. Cai, W.; Wang, F.; Zhan, E.; Van Veen, A.C.; Mirodatos, C.; Shen, W. Hydrogen production from ethanol over Ir/CeO 2 catalysts: A comparative study of steam reforming, partial oxidation and oxidative steam reforming. J. Catal. 2008, 257, 96-107. [CrossRef]

48. Sheng, P.Y.; Yee, A.; Bowmaker, G.A.; Idriss, $\mathrm{H}$. $\mathrm{H}_{2}$ Production from Ethanol over Rh-Pt $/ \mathrm{CeO}_{2}$ Catalysts: The Role of Rh for the Efficient Dissociation of the Carbon-Carbon Bond. J. Catal. 2002, 208, 393-403. [CrossRef]

49. Yee, A.; Morrison, S.J.; Idriss, H. A Study of Ethanol Reactions over $\mathrm{Pt} / \mathrm{CeO}_{2}$ by Temperature-Programmed Desorption and in Situ FT-IR Spectroscopy: Evidence of Benzene Formation. J. Catal. 2000, 191, 30-45. [CrossRef]

50. Yee, A.; Morrison, S.J.; Idriss, $\mathrm{H}$. The reactions of ethanol over $\mathrm{M} / \mathrm{CeO}_{2}$ catalysts: Evidence of carbon-carbon bond dissociation at low temperatures over $\mathrm{Rh} / \mathrm{CeO}_{2}$. Catal. Today 2000, 63, 327-335. [CrossRef]

51. Idriss, H. Ethanol Reactions over the Surfaces of Noble Metal/Cerium Oxide Catalysts. Platin. Met. Rev. 2004, 48, 105-115. [CrossRef]

52. Silchenkova, O.N.; Matyshak, V.A.; Bychkov, V.Y.; Korchak, V.N. Mechanism of Ethanol Conversion on a $5 \% \mathrm{CuO} / \mathrm{ZrO}_{2} \mathrm{Catalyst}$ According to In Situ IR-Spectroscopic Data. Kinet. Catal. 2020, 61, 460-465. [CrossRef]

53. Kukulska-Zając, E.; Góra-Marek, K.; Datka, J. IR and TPD studies of the reaction of acetic acid In zeolite NaHY. Microporous Mesoporous Mater. 2006, 96, 216-221. [CrossRef] 